\title{
The influence of surface fire on radial and height growth of Pinus sylvestris L. in forest-steppe in Ukraine
}

\author{
Iryna Koval $\bowtie$, Serhiy Sydorenko \\ G.M. Vysotskiy Ukrainian Research Institute of Forestry and Forest Melioration, Pushkinska 86, Kharkiv, 61024, Ukraine, \\ tel.+380577078045, e-mail: Koval_Iryna@ukr.net
}

\begin{abstract}
The article presents the results of the research on the peculiarity of response of Pinus sylvestris L. growth in height and diameter in young pine forest stand of the Left-Bank forest-steppe of Ukraine under the influence of surface fire that happened in May 2011. Forestry taxation, comparative ecology, standard dendrochronological methods were used. Response of trees was different for the height growth and the radial increment in the year of fire (2011). The radial growth got depressed in the year of fire; at the same time, the height of trees showed positive trend of growth against the background of favourable weather conditions. The growth in height was more ductile and completed its recovery to a particular level in 2014, unlike the radial growth, which recovered only in 2016. The relationships between radial growth on one side and stand sanitary state and height of bark char on the other were approximated by quadratic and cubic regression equations. Dynamics of pine growth depends on climatic factors also. Percentage of the late wood should be used to assess the condition of stands after fire. Research of post-pyrogenic development of forest ecosystems will allow more effective planning of forest management measures, and also allow the adjustment of the monitoring duration for pine forest stands damaged by fires.
\end{abstract}

\section{KeY WORDS}

meteorological characteristics, height growth, radial growth, post-pyrogenic development of pine stand, Pinus sylvestris $\mathrm{L}$., percent of the late wood

\section{INTRODUCTION}

Over the last years, attention has been focused on the problem of forest fires in the context of the increasing impact of such global processes as decrease of the world's forest areas, loss of biodiversity, climate change and change of land use (Flannigan et al. 2009; Zibtsev and Borsuk 2012; Hulida 2007; Sidorenko 2015; Rybalova and Belan 2011).
The factors that contribute to the risk of forest fires are: dominant anthropogenic factors and unfavourable weather conditions. Drought, as a complex of atmospheric processes, that is characterized by not more than $30 \%$ from the average of the precipitation monthly norm of the study area during 20 days, contributes to the emergence of fires (Gulak 2013).

In the case of fire regimes, Gill (1977) introduced the term 'type of fire', where he suggests a differentiation into subterranean ground fires and above-ground 
fires. The latter are further classified into surface and crown fires (Brown, 1995).

Fires played an important role in the natural dynamics of the forest-steppes, but human activity has modified the regeneration capacity of vegetation: for example, post-fire immigration of the native species is less efficient, due to habitat fragmentation. There were more light-demanding species in the burned section. The explanation for this may be that the canopy layer became more open due to the fire (Erdős 2014).

The growth in height and radial increment of trees, as complex factors that reflect the real condition of stands damaged by fires in terms of climate change, can be used for the study of the post-pyrogenic development of forest ecosystems (Van Wagner 1973; Schweingruber 1993; Koval 2010).

Different types of fires (crown fires, surface fires, ground fires [sometimes called underground or subsurface fires]) as described by Gil and Brown (Brown, 1995) can lead to a different response of tree height growth and radial increment. The fires affect the process of trees mortality and cause a negative reaction in trees that survive (Van Mantgem et al. 2009), especially if the trees are not adapted to changed climatic conditions (Parks, 2016). The fire resistance of trees is different for various species (Bauer et al. 2010).

The direct effect of fire on trees is due to its disturbance of physiological processes and the indirect influence changes the response of trees to climate variations and weakens the competition between trees due to death of some trees in the post-fire period (Hoffmann, 2002). In other words, the variability of the reaction of stands with regards to direct and indirect influences of surface fires on the growth of trees depends not only on tree species, but also on the inflow of additional moisture and nutrients for trees of all ages as a result of mortal-

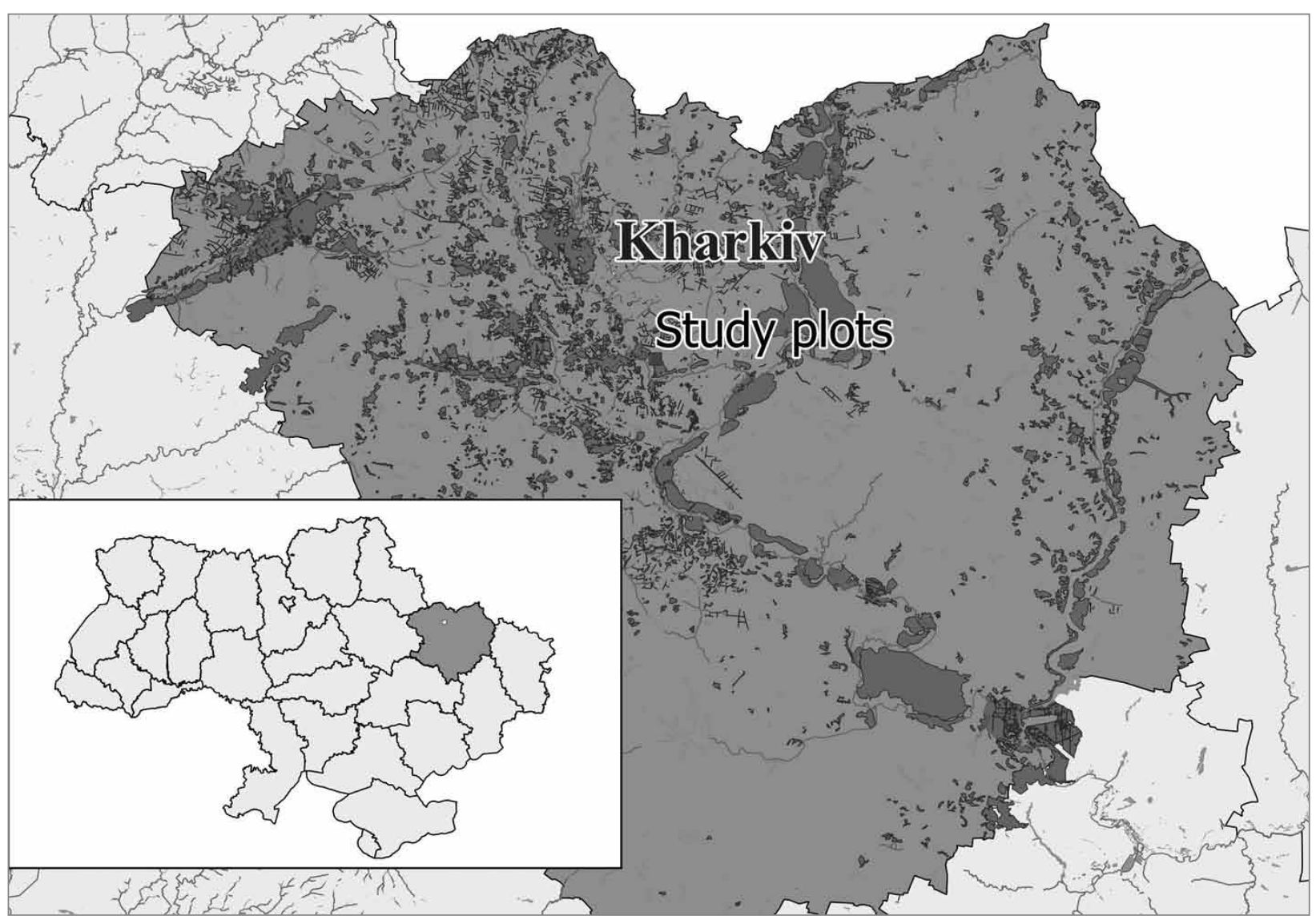

Figure 1. Geographical location of research object (location of test areas - latitude: 49,83152 N, longitude: 36,34255 E) 
ity of fire-damaged trees (González-Tagle et al. 2008; Mutch and Swetnam 1995; Skov et al. 2004; Riegel et al. 1992).

The main causes of forest fires in the forest-steppe zone of Ukraine are drought and anthropogenic impact (Sydorenko et al. 2015).

The questions regarding the influence of forest fires on stands are extremely important: Will the trees live after the fire, or die? Will forest fires of low intensity trigger the stand death? The quantitative relationships between behaviour of forest fire, fire characteristics and the amount of trees that are damaged and die are of practical interest to ecologists who study the response of tree stands after fires of varying intensity (Van Wagner 1973).

The purpose of this study was to reveal the peculiarity of the reaction of tree growth in height and diameter of Pinus sylvestris L. in young stand of the Left Bank Forest-steppe of Ukraine after surface fire.

\section{Material AND Methods}

Two permanent sample plots were established in a pure young pine stand in Wasischivske forestry (the quarter 9, site 2) in Kharkiv region. The first plot is located in the part of the forest damaged by a surface fire which occurred in May 2011 (Fig. 1); the second plot is located in an unaffected part of the same forest stand (control). The soil is soddy-podzolic. The age of the stand at the time of the damage by fire was 11 years.

Permanent study plots (PSP) are parts of one stand, so they are identical to tax rates. After a fire in 2011, significant drying trees were observed in the first year after the fire, which decreased over the next two years (Tab. 1).

The data of the Kharkiv meteorological station, located at a distance of $10 \mathrm{~km}$ northwest from the site of research, was used.

The climate is temperate continental. The warmest month $\left(21.9^{\circ} \mathrm{C}\right)$ and the wettest month $(70 \mathrm{~mm})$ was July, while the coldest month was January $\left(-4.6^{\circ} \mathrm{C}\right)$, with the lowest precipitation being February $(38 \mathrm{~mm})$ and March $(38 \mathrm{~mm})$. The climatograph of the Kharkiv meteorological station is presented in Figure 2.

PSP were selected and established in accordance with the generally accepted methods in forestry and forestry taxation with the further use of comparative ecology methods (Anuchin 1982; Grom 2010). Standard dendrochronological methods are also used (Bitvinskas 1974; Methods of Dendrochronology 1990).

The height of bark char on the stem was determined. Cores were selected for 15 trees by a Pressler borer from a tree trunk at a height of $1.3 \mathrm{~m}$. The tree ring widths were measured using digital HENSON equipment to an accuracy of $0.01 \mathrm{~mm}$. The dating of annual rings was carried out by skeletal graph method to define an exact calendar date for each. The tree ring data was averaged for each PSP (Cook and Kairiukstis 1990).

The tree-ring indices were calculated by three-year smoothing (Bitvinskas 1974). Comparison of graphs of the tree height, the tree radial growth, temperatures and precipitation were also carried out. Correlation and regression analysis was used to reveal the relationships between factors of growth in height and diameter on the one hand and the sanitary state of trees, Kraft classes,

Table 1. Characteristics of permanent study plots

\begin{tabular}{|c|c|c|c|c|c|c|c|c|c|c|c|c|c|c|c|}
\hline \multirow{2}{*}{ 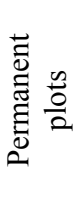 } & \multirow{2}{*}{ 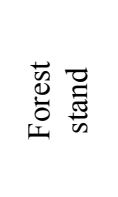 } & \multirow{2}{*}{ 裉 } & \multirow{2}{*}{ 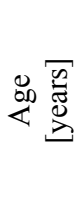 } & \multirow{2}{*}{ : } & \multirow{2}{*}{ 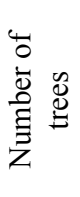 } & \multirow[b]{2}{*}{ ค } & \multirow[b]{2}{*}{ 汇 } & \multirow{2}{*}{ 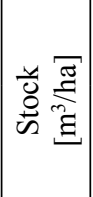 } & \multirow{2}{*}{ 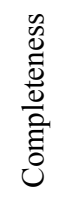 } & \multirow{2}{*}{ 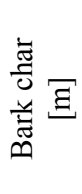 } & \multirow{2}{*}{ 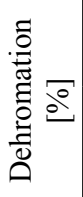 } & \multicolumn{4}{|c|}{$\begin{array}{c}\text { Post fire tree mortality } \\
{[\%]}\end{array}$} \\
\hline & & & & & & & & & & & & $\stackrel{\vec{\Xi}}{\stackrel{\Delta}{2}}$ & 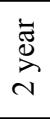 & $\begin{array}{l}\dot{\Xi} \\
\stackrel{\Delta}{\Delta} \\
m\end{array}$ & $\begin{array}{l}\stackrel{\vec{\Xi}}{\triangleright} \\
\stackrel{\nabla}{\nabla}\end{array}$ \\
\hline 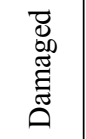 & 10 Pines & 828 & 18 & $\begin{array}{l}\text { May } \\
2011\end{array}$ & 233 & $6.1 \pm 0.17$ & $4.1 \pm 0,09$ & 9.2 & 0.9 & 1.05 & 61 & 24 & 5 & 0.6 & 0 \\
\hline $\begin{array}{l}\overline{0} \\
\text { 节 }\end{array}$ & 10 Pines & 385 & 18 & - & 117 & $5.5 \pm 0.21$ & $4.0 \pm 0.11$ & 9.0 & 0.9 & - & - & - & - & - & - \\
\hline
\end{tabular}




\section{sciendo}

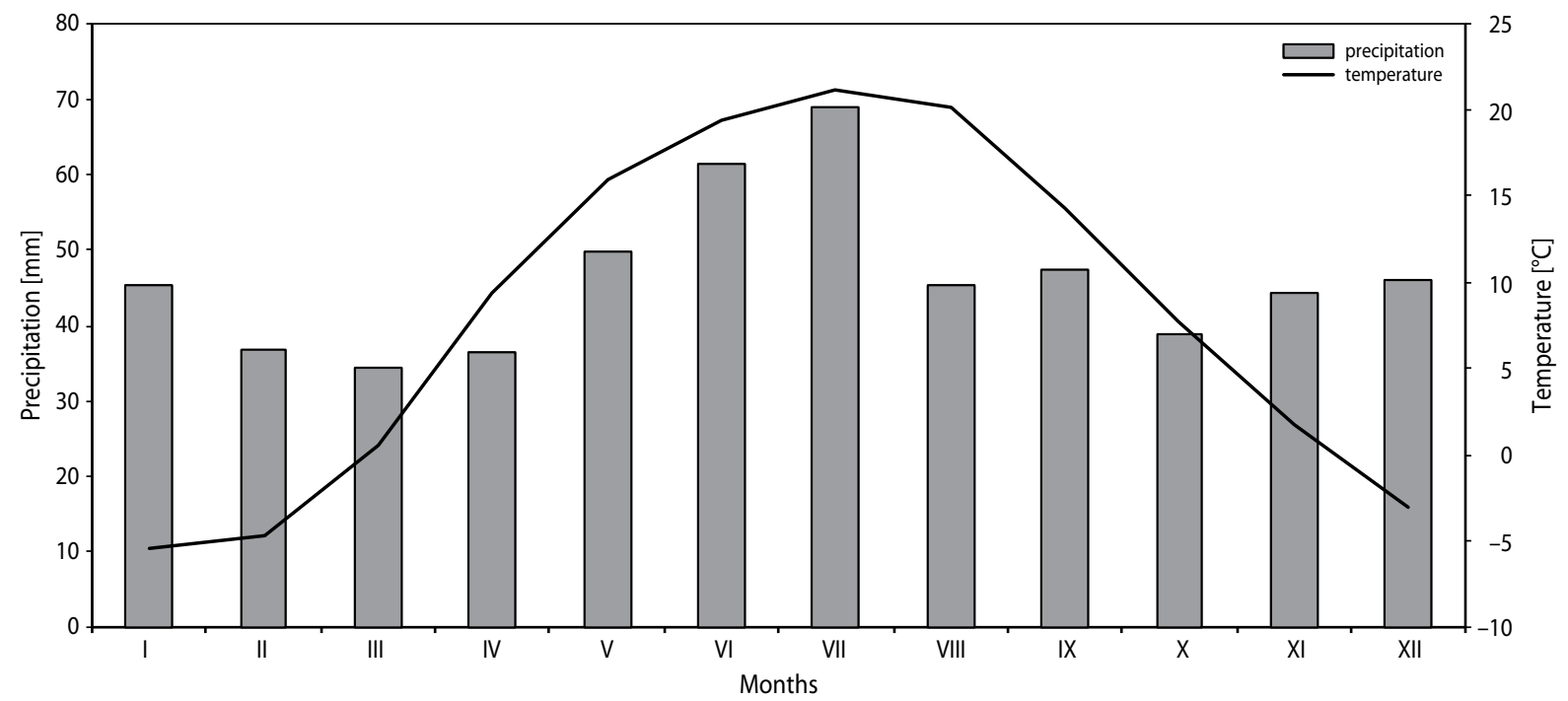

Figure 2. Climatograph of Kharkiv meteorological station for 1960-2018
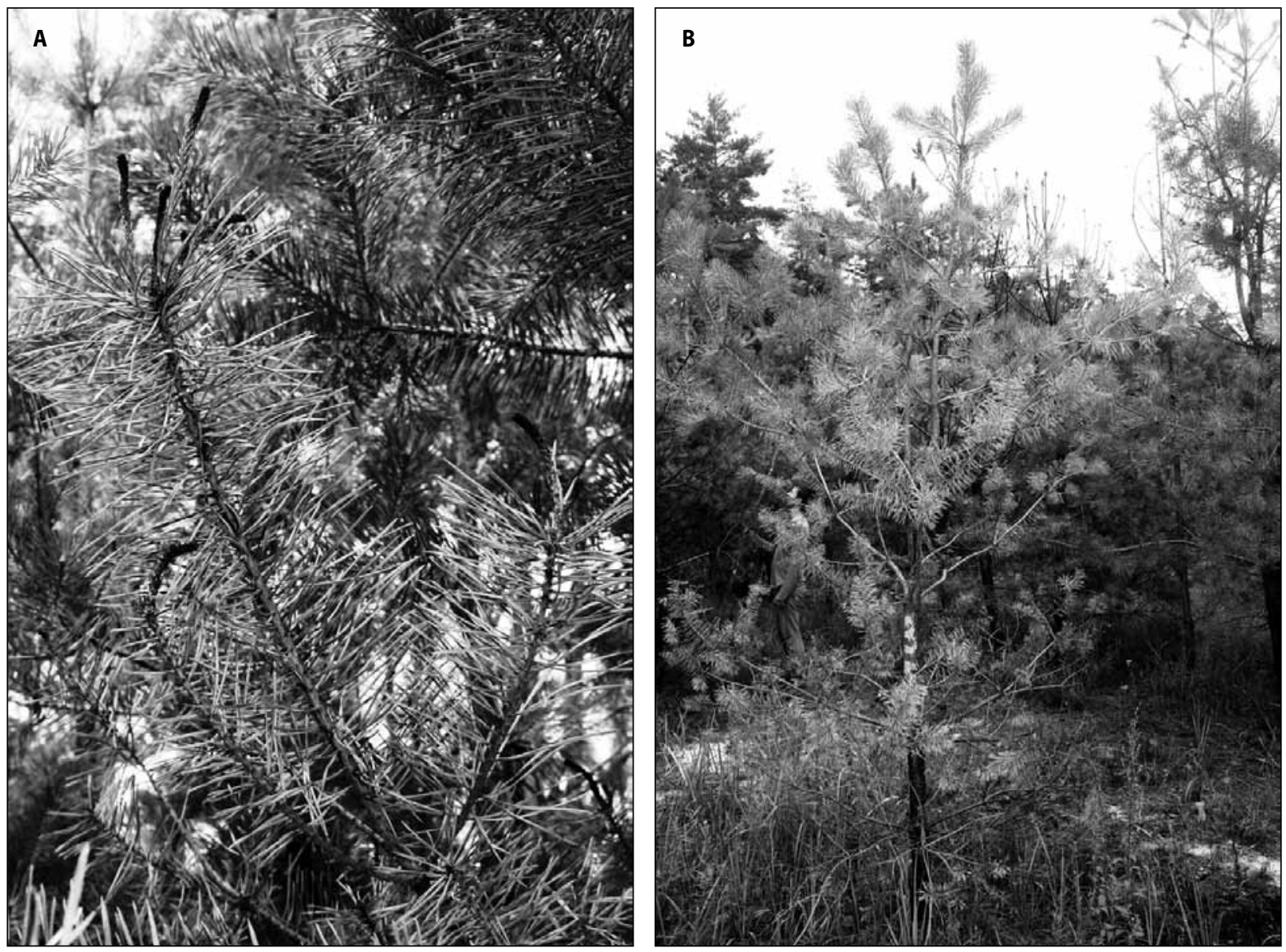

Figure 3. Crown damage by a surface fire in a pure pine young stand, A - pine shoots damaged by the fire; B - crown damaged by the fire 
the height of bark char on the trunk and climatic factors on the other.

\section{Results AND DISCUSSION}

The surface fire, which occurred in May of 2011, damaged the young pine stand. Since the litter and grass cover had low humidity, the fire developed quite quickly and led to severe damage to the tree stand. The dehromation of the needles (red-brown necrosis) spread from the bottom to the top of the tree and damage on the trunks was noted (Fig. 3 and 4).

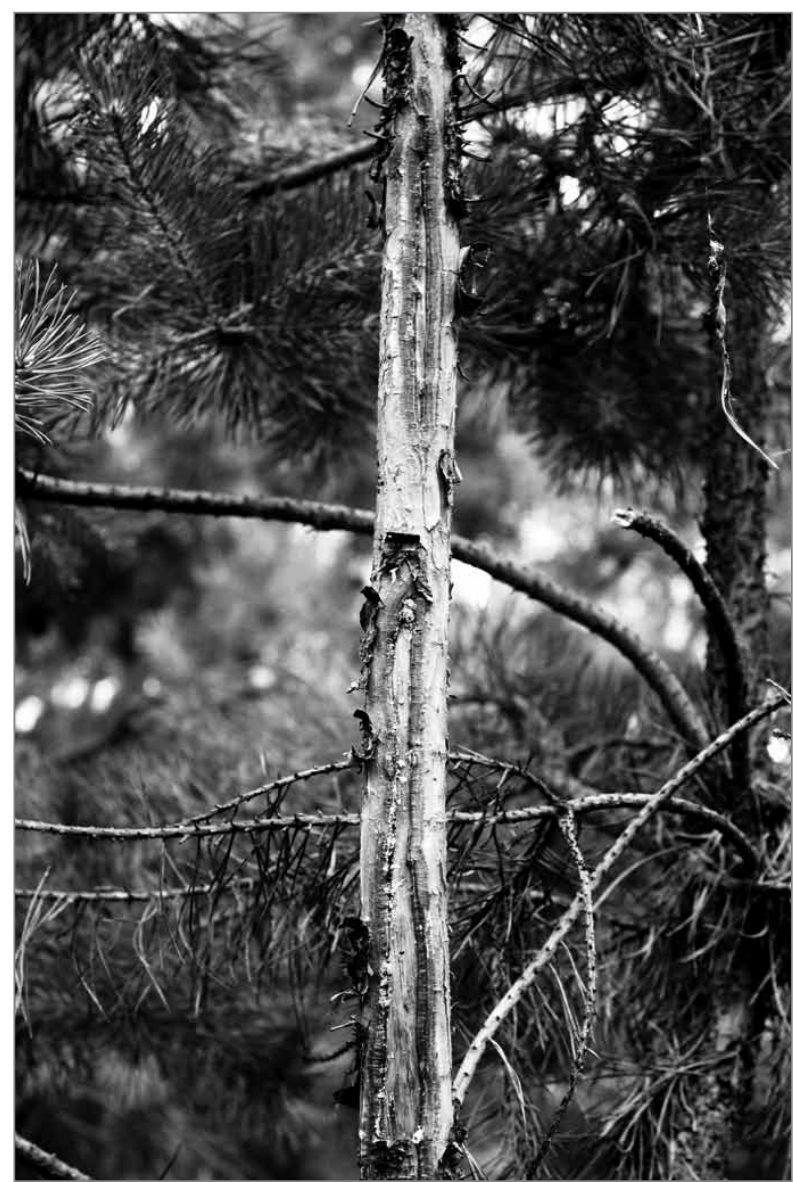

Figure 4. Post-fire scar of a 12-year-old pine in a damaged by fire pine stand in 2011

In two months after the fire, the sanitary condition of the stand was estimated as 'dying stand'. Such damage was aided by the low height of the placement of tree crowns (from 0.4 to $0.6 \mathrm{~m}$ ), while the average height of bark char on the stem was $1.1 \mathrm{~m}$, and the maximum $-4.5 \mathrm{~m}$. In such conditions, surface fire often becomes crown fire; however, this did not happen, since the trunks, buds and needles had high humidity at the time of the fire.

Dynamics of the growth of the pine trees in height and the radial increment of trees in the stand damaged by the surface fire in 2011 and at the control are presented on Figure 5 and 6.

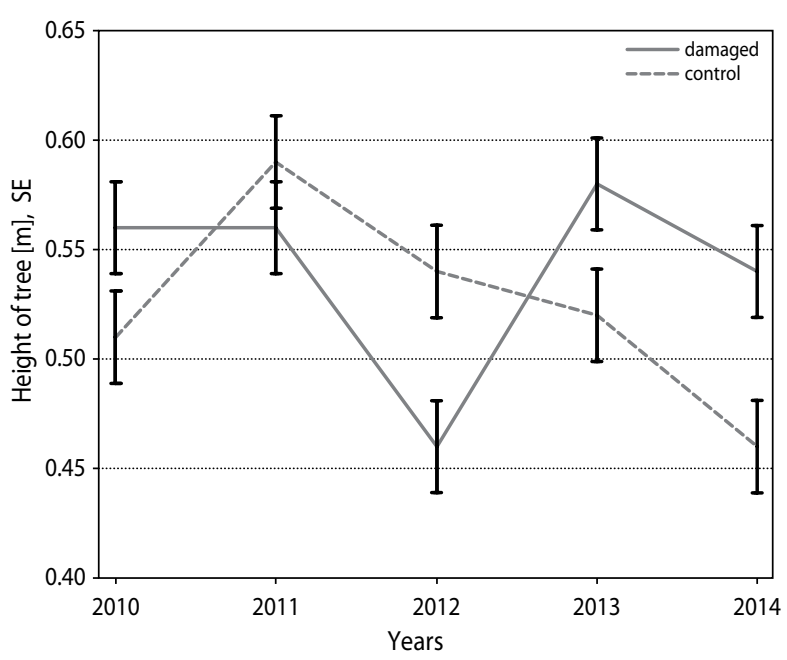

Figure 5. Dynamics of the growth of the pine trees in height in the stand damaged by the surface fire in 2011 and at the control

After-fire scars were noted in $61.5 \%$ of the trees (the drying was noticed 2 years after damage to the living trees), indicating local damage to their cambium layers during the fire (Fig. 4).

The fire occurred on the background of favourable weather conditions for tree growth (the vegetation season was warm and humid), which led to mitigating the effects of the fire on the stand. Precipitation in AprilAugust fell by $37 \%$ compared to the average values for 2007-2017 (norm), and temperatures almost did not deviate from the norm $\left(18.1^{\circ} \mathrm{C}\right)$ during the growing season (Fig. 7 and 8).

The fire damaged the young pine stand during the 'active growth period'. The growth of trees is influenced by both internal and external factors that cause different tree reactions in different periods of ontogenesis. The beginning of growth in height corresponds to 


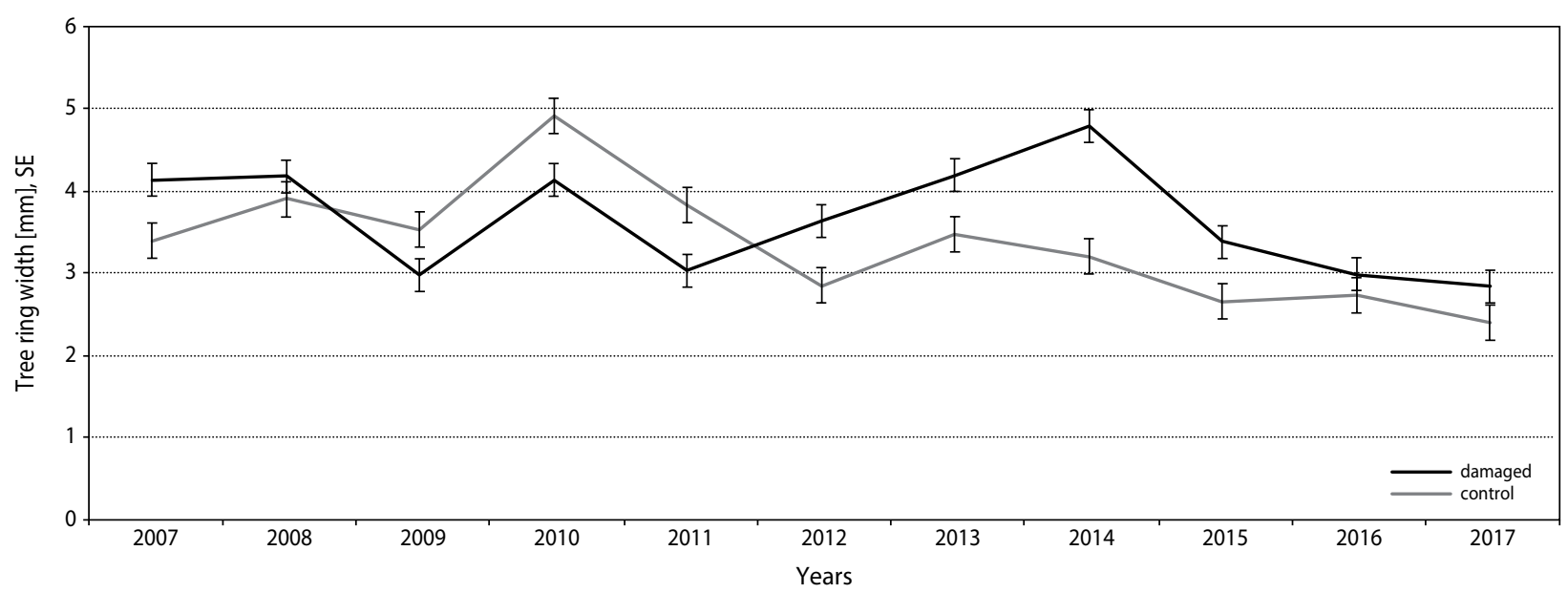

Figure 6. Dynamics of the radial growth of the pine in the stand damaged by the surface fire

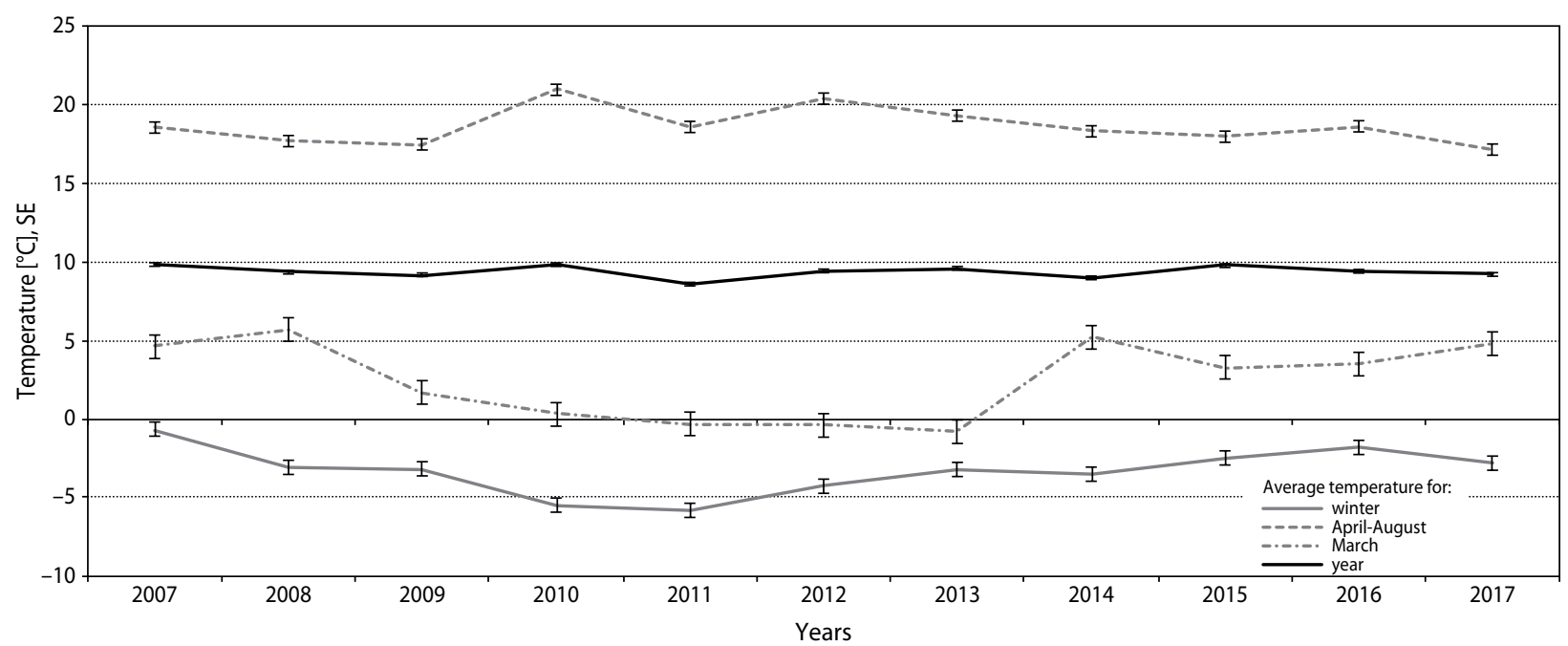

Figure 7. Temperatures at the Kharkiv meteorological station

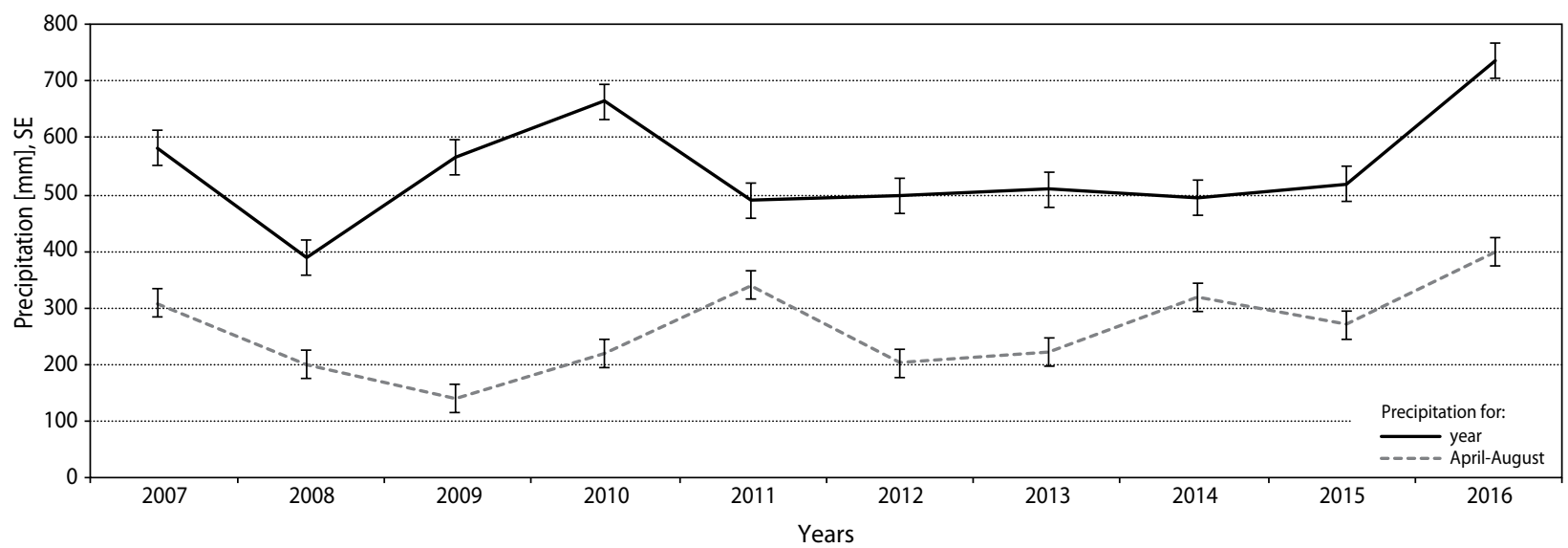

Figure 8. Precipitation at the Kharkiv meteorological station 
the beginning of the elongation of the central bud. The beginning of the period of active growth is the opening of the apical bud and the formation of a central shoot. For our study area, this is the third decade, April to the first half of May (Rusalenko 1986). The average annual growth of trees in the height of the year of the fire was $5 \%$ higher than in the fire-damaged trees (Fig. 5). The average temperature in the year of the fire during AprilMay was $4 \%$ below the norm, and the precipitation fell on the contrary by $4 \%$ during this period.

The growth of trunks in diameter, mainly, coincides with the period of the active extension of the central shoot, which happens in the second half of May (Rusalenko 1986). Climatic factors during May-June of the then vegetation season in the year of the fire damage had a positive effect on radial growth. During that period, the postembryonic stage of the assimilation apparatus and the annual ring in the pine trees were formed. The May-June precipitation fell by $87 \%$ below the average within the period of 2007-2017.

At the time of the beginning of the fire (the beginning of May), the growth in height was partially formed, and the formation of tree rings only became an active stage. This can be explained by the maximum increments in the height of both the control and the damaged plot unlike the radial increment.

In the following year, 2012, a decrease in the height growth of the damaged trees was noted at $15 \%$ compared to the control, on the background of negative weather conditions. During the growing season, the temperature decreased by only $9 \%$, but precipitation fell by $19 \%$ less than the norm. Two years after the fire, in 2013, a sharp increase in the height of the damaged trees was observed, which resulted from the fall of trees that had been weakened by fire, resulting in an increase in the light increment and the supply area of the trees that survived. In 2014, there was a tendency to decrease in the growth of damaged trees.

It was revealed, that radial growth of the fire damaged trees (2011) was less than the control by $20 \%$. In 2012-2017, we discovered that the increase in the radial growth in comparison with the control was as a result of increased areas of nutrition of the surviving trees. Trend of increase of the dynamic of growth in tree height after the fire was noted in 2013 and for radial growth during 2012-2014. In 2016-2017, radial growth had reached a level before the fire.
Depression of radial growth was detected in the control plot in 2009, 2012 (for the control plot) and 2015, which can be explained by the annual minimum precipitation in the growing season, and for 2012, by the high temperatures for the year and vegetation periods (Fig. 6-8). For damaged trees, the minimum radial gain was also observed in 2009 and 2015, and in the year of the fire, in 2011.

Statistically significant differences were found between the average values of tree heights in the year of fire (2011), and in 2012 and 2013. In 2011, this difference was $10.5 \%$, in $2012-11.7 \%$ and in $2013-10.5 \%$ (Tab. 2).

Table 2. Difference in mean values of tree heights damaged by the fire in 2011 and the control. Estimation of the significance of difference in the sample mean by t-criterion

\begin{tabular}{|l|c|c|c|}
\hline \multicolumn{1}{|c|}{$\begin{array}{c}\text { Height } \\
{[\mathrm{m}]}\end{array}$} & $\begin{array}{c}\text { Year of the } \\
\text { fire, 2011 }\end{array}$ & $\begin{array}{c}\text { Second year } \\
\text { after the fire, } \\
2012\end{array}$ & $\begin{array}{c}\text { The third } \\
\text { year after the } \\
\text { fire, 2013 }\end{array}$ \\
\hline Damaged plot & $4.01 \pm 0.10$ & $4.46 \pm 0.10$ & $4.93 \pm 0.10$ \\
\hline $\begin{array}{l}\text { Control } \\
\text { (unburned) }\end{array}$ & $4.48 \pm 0.11$ & $5.06 \pm 0.11$ & $5.51 \pm 0.11$ \\
\hline t-value & $3.16^{* *}$ & $4.03 * * *$ & $3.90^{* *}$ \\
\hline t-table & $2.58_{0.01}$ & $3.29_{0.001}$ & $3.29_{0.001}$ \\
\hline
\end{tabular}

Notes: $* *-\mathrm{p} \leq 0.01 ; * * *-\mathrm{p} \leq 0.001$; statistically significant differences.

In previous research about the influence of fire on height of trees in forest-steppe zone in young stand, we have revealed that intensive mortality of damaged trees occurs in the first year after the fire. In the young stands, the processes of mortality and restoration of trees continue at the same time, and in the second year, the processes of deterioration are slowed down. In the third year, the processes of tree restoration prevailed. Young trees of pine die at $80 \%$ burn of crowns. The critical level of damage to the tree trunk is the relative char of more than $60 \%$ (relative char is the ratio of the height of the tree to the height of the bark char, \%) when more than $70 \%$ of trees die (Sydorenko 2014).

A significant difference was found between the annual wood at the control PSP and the damaged PSP for 2014. For late wood, this difference was revealed for 2012, and for early wood, for 2014. That is, the fastest reaction to the fire damage was late wood, which is formed under the influence of the weather conditions of the growing season of the current year, and later on, 
because it is more plastic, formed under the influence of weather conditions of previous years and winter vegetation period of the current year (Tab. 3).

The proportion of late wood, which is an indicator of the tree condition, indicates that during 2011-2013, the damaged stand was in depression, and in the following years 2014-2017, we relived a small difference in percentages of late wood in the control and the damaged part of stand, indicating that recovery in the radial growth of trees surviving after the fire. In 2016, the growth of trees in the damaged area equalled that of the control. In 2017, the radial growth of the surviving trees slightly deteriorated compared with the control (Fig. 9).

A correlation analysis was carried out between the indices of radial growth on the one site and the sanitary condition, the classes of Kraft, tree height, weight loss, tree diameters, the height of the bark char and defolia-

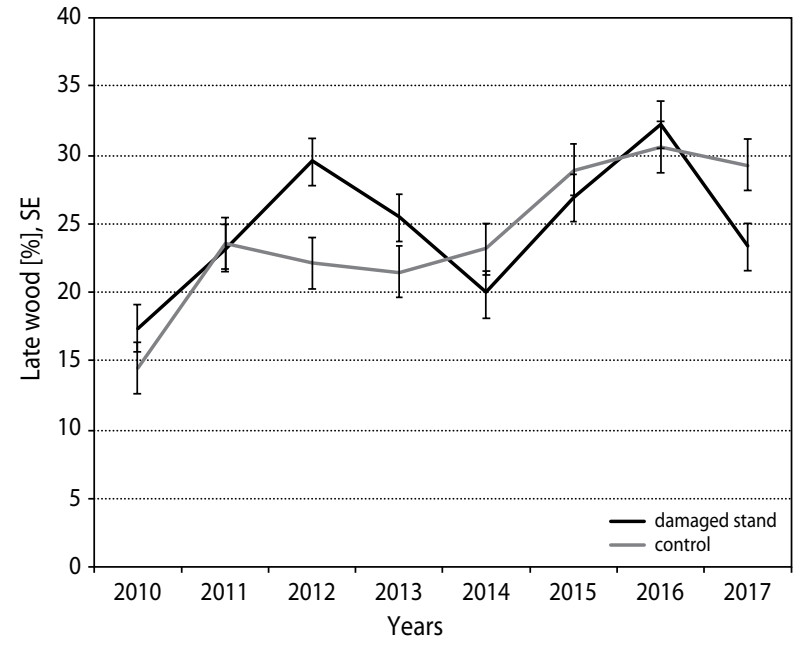

Figure 9. Percentage of pine trees late wood in the young stand

Table 3. The difference in the mean values of the layers of early, late and annual wood in stand damaged by fire and at the control. Estimation of the significance of the difference in the sample mean by the t-criterion

\begin{tabular}{|c|c|c|c|c|c|c|c|c|}
\hline Plot & $\begin{array}{c}\text { A year } \\
\text { before fires } \\
2010\end{array}$ & $\begin{array}{c}\text { The year of } \\
\text { the fire, } \\
2011\end{array}$ & $\begin{array}{c}\text { The second } \\
\text { year after } \\
\text { fires, } \\
2012\end{array}$ & $\begin{array}{c}\text { The third } \\
\text { year after } \\
\text { the fire, } \\
2013\end{array}$ & $\begin{array}{l}\text { The fourth } \\
\text { year after } \\
\text { the fire, } \\
2014\end{array}$ & $\begin{array}{c}\text { The fifth } \\
\text { year after } \\
\text { the fire, } \\
2015\end{array}$ & $\begin{array}{c}\text { The sixth } \\
\text { year after } \\
\text { the fire, } \\
2016\end{array}$ & $\begin{array}{c}\text { The seventh } \\
\text { year after } \\
\text { the year, } \\
2017\end{array}$ \\
\hline \multicolumn{9}{|c|}{ Annual wood } \\
\hline Damaged & $4.14 \pm 0.58$ & $3.03 \pm 0.52$ & $3.63 \pm 0.31$ & $4.19 \pm 0.42$ & $4.79 \pm 0.39$ & $3.38 \pm 0.28$ & $2.99 \pm 0.37$ & $2.84 \pm 0.15$ \\
\hline $\begin{array}{l}\text { Control } \\
\text { (unburned) }\end{array}$ & $4.91 \pm 0.51$ & $3.83 \pm 0.56$ & $2.85 \pm 0.41$ & $3.47 \pm 0.42$ & $3.21 \pm 0.30$ & $2.66 \pm 0.31$ & $2.73 \pm 0.31$ & $2.40 \pm 0.17$ \\
\hline t-value & 1.01 & 1.04 & 1.51 & 1.21 & $-3.23 *$ & -1.72 & -0.54 & -1.95 \\
\hline t-table & 2.07 & 2.07 & 2.07 & 2.07 & $2.07_{0.05}$ & 2.07 & 2.07 & 2.07 \\
\hline \multicolumn{9}{|c|}{ Late wood } \\
\hline Damaged & $0.72 \pm 0.08$ & $0.70 \pm 0.07$ & $1.07 \pm 0.13$ & $1.07 \pm 0.15$ & $0.95 \pm 0.20$ & $0.91 \pm 0.13$ & $0.96 \pm 0.11$ & $0.66 \pm 0.04$ \\
\hline $\begin{array}{l}\text { Control } \\
\text { (unburned) }\end{array}$ & $0.71 \pm 0.11$ & $0.90 \pm 0.17$ & $0.63 \pm 0.08$ & $0.75 \pm 0.12$ & $0.74 \pm 0.15$ & $0.77 \pm 0.12$ & $0.84 \pm 0.11$ & $0.70 \pm 0.07$ \\
\hline t-value & 0.05 & 0.98 & $-2.92 *$ & 1.64 & 0.81 & 0,79 & -0.82 & 0.52 \\
\hline t-table & 2.07 & 2.07 & $2.07_{0.05}$ & 2.07 & 2.07 & 2.07 & 2.07 & 2.07 \\
\hline \multicolumn{9}{|c|}{ Early wood } \\
\hline Damaged & $3.42 \pm 0.54$ & $2.33 \pm 0.48$ & $2.56 \pm 0.42$ & $3.13 \pm 0.38$ & $3.84 \pm 0.37$ & $2.47 \pm 0.25$ & $2.03 \pm 0.28$ & $2.18 \pm 0.13$ \\
\hline $\begin{array}{l}\text { Control } \\
\text { (unburned) }\end{array}$ & $4.17 \pm 0.50$ & $2.91 \pm 0.49$ & $2.24 \pm 0.38$ & $2.73 \pm 0.37$ & $2.46 \pm 0.23$ & $1.89 \pm 0.27$ & $1.9 \pm 0.24$ & $1.70 \pm 0.13$ \\
\hline t-value. & 1.02 & 0.85 & -0.57 & 0.75 & $3.17^{*}$ & 1.59 & 0.34 & -2.61 \\
\hline t-table & 2.07 & 2.07 & 2.07 & 2.07 & $2.07_{0.05}$ & 2.07 & 2.07 & 2.07 \\
\hline
\end{tabular}

Notes: $*-p \leq 0.05$; statistically significant differences. 
tion - on the other site. Dependence was noted between the indices of radial growth of pine trees on the damaged plot for 2011 and the index of sanitary condition for 2012, which was approximated by the curve of the 2nd order $\left(\mathrm{y}=0.83 ; \mathrm{t}_{\text {fact }}=24.4 ; \mathrm{t}_{\text {teor }}=4.78\right.$ at the level of 0.001 significance) (Fig. 10). Also, regression dependence between the radial growth indices for 2013 and

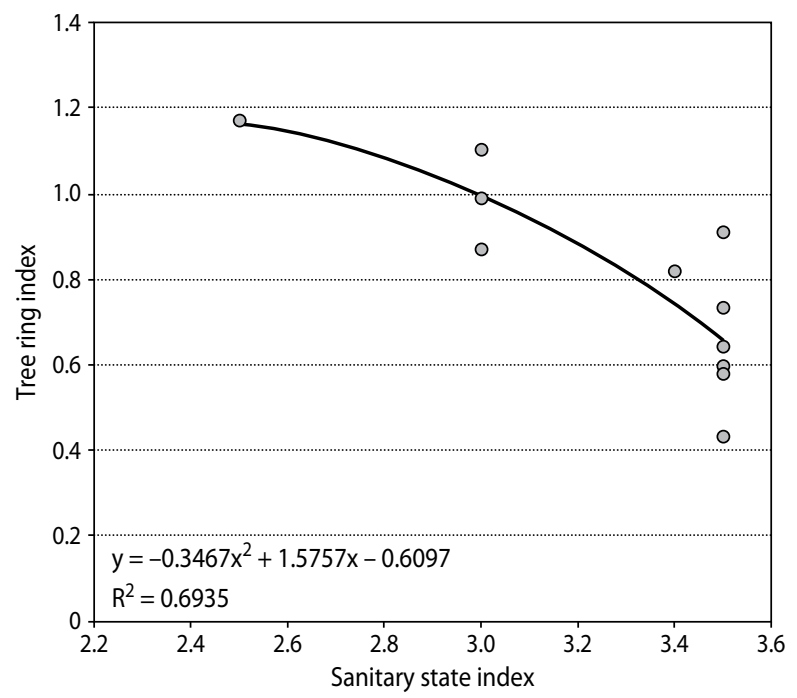

Figure 10. Regression dependence between the indices of radial growth in 2011 and the indices of the sanitary condition in 2012 on the plot damaged by fire

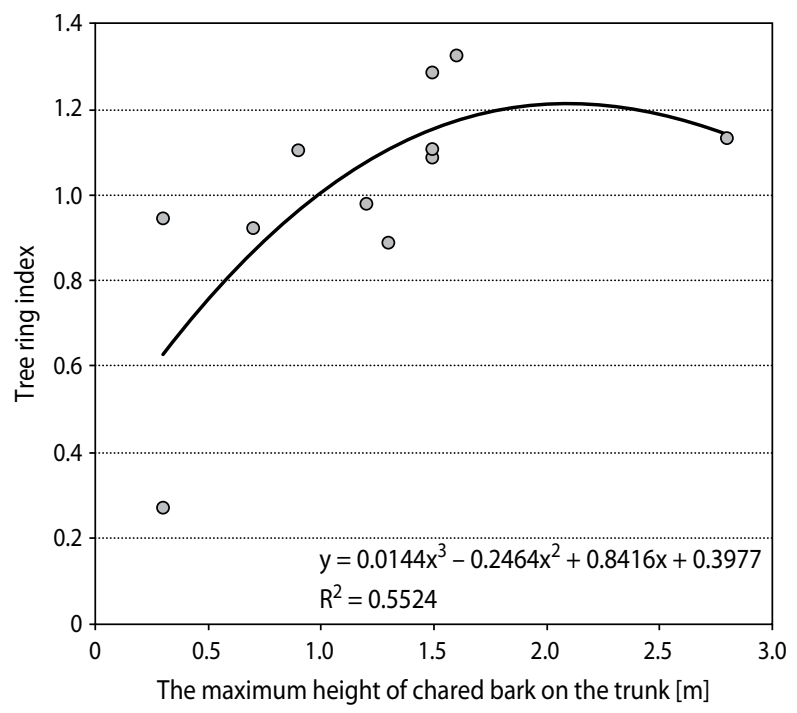

Figure 11. Regression dependence of the radial growth indices for 2013 and the maximum height of the bark char on the trunks for 2011 the maximum level of 2011, which was described by the curve of the second order, was calculated $(\eta=0.74$; $\mathrm{t}_{\text {fact }}=3.33 ; \mathrm{t}_{\text {theor }}=3.25$ at the 0.01 significance level) (Fig. 11).

Low intensity fires can cause cambial damage, but only in trees with a thin bark, or young trees in which a thick bark has not yet formed. It is known that bark, up to $3.5 \mathrm{~mm}$ thick, is not able to protect the cambium from thermal damage during the fire; so, after 2 minutes of high temperatures $\left(185^{\circ} \mathrm{C}\right)$, the temperature of the precambial tissues of the tree reaches the lethal level (Furayev 2008). Thus, the depression of the growth of damaged trees can be characterized by the intensity and duration of the fire, as well as the fire regime (repeated fire) (Rötzer et al. 2012; Seifert et al. 2017). The intensity and duration of the fire in retrospect can be expressed only by the bark char on the trunks and the proportion of consumed forest fuel load, especially litter. The altitude that can be seen on the tree trunk for several consecutive seasons is not always an indicator of damage to the cambium, since the bark isolates and protects it from the effects of high temperatures. In young pine plantations, in which the trees do not yet have a wellformed thick bark (Odhiambo 2014; Wesolowski 2014; Seifert et al. 2017). During high-temperature fires, cambium can be killed locally, resulting in specific damage - post-fire scars that are permanent markers of forest fires (Smith et al. 2016; Seifert et al. 2017).

In order to predict the response to the increase in the impact of the fire, it is important to understand the reaction of the tree to thermal damage (Elliott et al. 2002; Hoffmann 2002). Biophysical and biochemical violations caused by the effect of high temperatures are to some extent reflected due to depression of growth in height and diameter. Also, such an effect can be expressed by the change in the proportions of early and late wood (Makkonen et al. 2016; Seifert et al. 2017). With the help of the indicator of the proportion of late wood, the duration of the period of weakening of the trees damaged by fire, when the proportion of the later wood in the damaged part of the plant exceeded, a similar indicator in the control was revealed. Drobyshev et al. (2004) stated that the duration of the impact of the fire during the growing season on the growth is characterized by the proportion of the late wood.

Typically, when the growth of trees in diameter is affected by the effect of the fire (Ford et al. 2010; Seif- 
ert 2017), such a decrease in growth is described by the author as a short-term phenomenon that lasts from 1 to 3 years, after which the rate of growth returns to the state of emergency (Murphy et al. 2010; Seifert et al. 2017). This assumption is mainly based on studies of the effects of damage to crowns during a fire, where photosynthetic capacity is disturbed due to the loss of part of assimilation in the trees (Wallin et al. 2003; Seifert et al. 2017).

Significant decrease in height in the year of the fire was not noted, because the growth was already established (the fire occurred at the end of May). In contrast to the increase in height, the radial growth, which was in the active formation stage in early May and ended mainly in August, reacted with deep depressions. Such a strong reaction can be explained by the fact that it was established mainly in the plants damaged by the fire. The fire has led to the decline in growth and death of weakened trees, significantly accelerating the process of natural thinning in the stand. Due to these processes, competition for light and resources of nutrition has weakened. The growth in height was more ductile and completed its recovery to a level in 2014, unlike radial growth, which recovered only in 2016. Late wood was most sensitive to the effects of fire than early and annual wood.

We have compared our results about the radial growth of young pine trees after fire with the pine ring widths in middle-aged pine stands after fire in forest and forest-steppe zones with same level of damage (the mean chair bark was $1.76-1.82 \mathrm{~cm}$ for both stands). In the forest zone in three years after the fire, there was no regeneration of the radial growth of trees in contrast to the stand in the forest-steppe, where during two years the radial growth restored (Koval et al. 2017). So, for young stand, we have got result like in the middle-age pine stand in the forest-steppe zone.

The study about impact surface fires on $P$. radiata tree width in the stand of South Africa, in conditions of a typical Mediterranean climate, provided evidence that growth reductions might be carried to the year following the fire event and can last up to 3 years before pre-fire growth levels are restored (Seifert et al. 2017).

The influence of low-intensity surface fires were investigated on the development of ground vegetation and tree growth in Scots pine (Pinus sylvestris) stands on sandy soils in eastern part of Lithuania. Investigations show, that low intensity surface fires didn't affect annual radial increment. The radial growth of tree has not changed after low intensity surface fire. Scots pine trees are a fire-tolerant species and can survive low severity surface fires (Marozas et al. 2011).

\section{Conclusion}

Pine trees that did not die during the first two years after the fire (May, 2011) were successfully restored in 2014-2016.

The growth in height was more ductile and completed its recovery in 2014, unlike radial growth, which recovered only in 2016 in the conditions of forest-steppe zone.

Percent of the late wood should be used to assess the condition of stands after fire and to establish the duration of the period of weakening and vulnerability of damaged trees in stands. Such data will allow more effective planning of forest management measures, and will allow for adjusting the monitoring duration for young pine forest stands damaged by fires.

\section{RefERENCES}

Anuchin, N. 1982. Forest Mensuration. Moscow, Lesnaya Promyshlennost.

Bauer, G., Speck, T., Blömer, J. 2010. Insulation capability of the bark of trees with different fire adaptation. Journal of Material Science, 45, 5950-5959.

Bitvinskas, T. 1974. Dendroclimatic studies. Gidrometeoizdat Publishing House, Leningrad, USSR (in Russian).

Brown, J. 1995. Fire regimes and their relevance to ecosystem management. Proceedings of the society of American forester's, 1994 national convention, 171-178.

Cook, E., Kairiukstis, L. 1990. Methods of Dendrochronology - Applications in the Environmental Sciences, Doredrecht, the Netherlands.

Drobyshev, I., Niklasson, M., Angelstam, P. 2004. Contrasting tree-ring data with fire record in a pinedominated landscape in the Komi Republic (eastern European Russia): recovering a common climate signal. Silva Fennica, 38, 43-53. 
Elliott, K., Vose, J., Clinton, B. 2002. Growth of eastern white pine Pinus strobus L. related to forest floor consumption by prescribedm fire in the southern Appalachians. Southern Journal of Applied Forestry, 26, 18-25.

Erdős, L. 2014. Post-fire regeneration of a forest-steppe: vegetation status 20 years after the fire. Tiscia, 40, $11-15$.

Flannigan, M., Krawchuk, M., de Groot, W., Wotton, B., Gowman L. 2009. Implications of changing climate for global wildland fire. International Journal of Wildland Fire, 18, 483-507.

Ford, C., Emily, S., Gordon A. 2010. Long-term effects of fire and fire-return interval on population structure and growth of longleaf pine (Pinus palustris). Canadian Journal of Forest Research, 40, 1410-1420.

Furayev V.V. 2008. Piroecological properties of Scots pine in Middle Siberia. Coniferous boreal zone, 103-108.

Gill, A.M. 1975. Fire and the Australian flora: a review. Australian Forestry, 38, 4-25.

González-Tagle, M., Schwendenmann, L., Pérez, J., Schulz, R. 2008. Forest structure and woody plant species composition along a fire chronosequence in mixed pine-oak forest in the Sierra Madre Oriental, Northeast Mexico. Forest Ecology and Management, 256, 161-167.

Grom, M. 2007. Forest mensuration, Lviv.

Gulak, O. 2013. Preservation of fire safety of forests at the present stage of development of our state. Scientific Herald of NULES of Ukraine, 182, 190-194.

Hoffmann, W. 2002. Direct and indirect effects of fire on radial growth of cerrado savanna trees. Journal of Tropical Ecology, 18, 137-142.

Hulida, E. 2007. Predicting the spread of forest fires. Fire Safety Problems, 21, 73-79.

Koval, I. 2010. Radial growth as an indicator of forest ecosystem stability on the example of pine forests of the green zone of Kharkiv. Scientific Bulletin of the National University of Life and Environmental Sciences of Ukraine, 147, 223-232.

Koval, I., et al. 2017. Dendrochronological aspects of post-pyrogenic development of pine stands in Polissya and Forest-Steppe. In: Proceedings of Kharkiv National University named after V.N. Karazin Conference "XIII Ukrainian scientific Taliiv reading",
14-16 April 2017 (eds.: N.V. Maksymenko, S.A. Baliuk). Kharkiv, Ukraine, 28-31.

Makkonen, S., Huuhilo, K., Utriainen, J., Holopainen, T, Kainulainen, P. 2016. Radial ring width and wood structure in the ozone-exposed Norway spruce seedlings grown under different nitrogen regimes. Boreal Environment Researches, 21, 149-165.

Murphy, B., Russel-Smith, J., Prior, L. 2010. Frequent fires reduce tree growth in northern Australian savannas: implications for tree demography and carbon sequestration. Global Change Biology, 16, 331-343.

Marozas, V., Plaušinyte, E., Augustaitis, A., Kačiulyte, A. 2011. Changes of ground vegetation and treering growth after surface fires in Scots pine forests. Acta Biol. Universit. Daugavpil., 11 (2), 156-162.

Mutch, L., Swetnam, T. 1995. Effects of fire se-verity and climate on ring-width growth of giant sequoia after burning. Proceedings: Symposium on Fire in Wilderness and Park Management. Forest Service General Technical Report Intermoun-tain, 320, 241-246.

Odhiambo, B., Meincken, M, Seifert, T. 2014. The protective role of bark against fire damage: a comparative study on selected introduced and indigenous tree species in the Western Cape, South Africa. Trees, 28, 555-565.

Parks, S., Miller, C., Abatzoglou, J., Holsinger, L., Parisien, M., Dobrowski, S. 2016. How will climate change affect wildland fire severity in the western US? Environmental Research Letters, 3, 3-10.

Riegel, G., Miller, R., Krueger, W. 1992. Competition for resources between understory vegetation and overstory Pinus ponderosa in Northeastern Oregon. Ecological Applications, 2, 71-85.

Rötzer, T., Seifert, T., Gayler, S., Priesack, E., Pretzsch, H. 2012. Effects of Stress and Defence Allocation on Tree Growth: Simulation Results at the Individual and Stand Level. In: Tracing Carbon Fluxes: Resolving Complexity Using Isotopes (eds.: R. Matyssek, H. Schnyder, W. Oßwald, H. Pretzsch). Technische Universitat Munchen, 401-432.

Rusalenko, A. 1986. Annual growth of trees and moisture supply. Science and Technology, Minsk, Belarus.

Rybalova, O., Belan, S. 2011. Measures to reduce the impact of forest fires on the ecological state of small 


\section{sciendo}

rivers. East European Journal of Advanced Technologies, 6, 52-56.

Schweingruber, F. 1993. Trees and wood in dendrochronology. Morphological, anatomical, and tree-ring analytical characteristics of trees frequently used in dendrochronology. Berlin, New York.

Seifert, T., Meincken, M., Odhiambo, B. 2017. The effect of surface fire on tree ring growth of Pinus radiata trees. Annals of Forest Science, 34-74.

Skov, K., Kolb, T., Wallin, K. 2004. Tree size and drought affect ponderosa pine physiological response to thinning and burning treatments. Forestry Science, $50,81-91$.

Smith, K., Arbellay, E., Falk, D., Sutherland, E. 2016. Macroanatomy and compartmentalization of recent fire scars in three North American conifers. Canadian Journal of Forest Research, 46, $535-542$

Sydorenko, S., Voron, V., Melnik, E., Sydorenko, A. 2015. Peculiarities of the mature pine stands forma- tion after surface fires. Forestry and Forest Melioration, 157, 169-176.

Van Mantgem, P., Stephenson, N., Byrne, J., Daniels, L., Franklin, J. 2009. Widespread increase of tree mortality rates in the western United States. Science, 323, 521-524.

Van Wagner, C. 1973. Height of crown scorch in Forest fires. Canadian Journal of Forest Research, 3, 373-378.

Wallin, K., Kolb, T., Skov, K., Wagner, M. 2003. Effects of crown scorch on ponderosa pine resistance to bark beetles in Northern Arizona. Environmental Entomology, 32, 652-661.

Wesolowski, A., Adams, M., Pfautsch, S. 2014. Insulation capacity of three bark types of temperate $E u$ calyptus species. Forest Ecology and Management, 313, 224-232.

Zybtsev, S., Borsuk, O. 2012. Forest Protection from Fires in the World and in Ukraine. Challenges of the XXI Century and Development Prospects, 1, 49-63. 